IBIMA Publishing

Journal of Eastern Europe Research in Business and Economics

http://ibimapublishing.com/articles/JEERBE/2020/108960/

Vol. 2020 (2020), Article ID 108960, 7 pages, ISSN : 2169-0367

DOI: $10.5171 / 2020.108960$

Research Article

\title{
Arctic Strategies for Socio-Economic Development of Circumpolar States: National and Regional Aspects
}

\author{
Vera SAMARINA ${ }^{1}$, Tatiana SKUFINA ${ }^{2}$, Elena KORCHAK ${ }^{3}$, Natalia SEROVA and \\ Aleksandr SAMARIN ${ }^{4}$
}

${ }^{1,2,3}$ Federal Research Centre Kola Science Centre of the Russian Academy of Sciences

${ }^{4}$ Belgorod State National Research University (Staryy Oskol Branch), Staryy Oskol, Russia

Correspondence should be addressed to: Vera SAMARINA; samarina_vp@mail.ru

Received date:23 January 2020 ; Accepted date: 8 July 2020; Published date: 29 July 2020

Academic Editor: Anastasiya Kopytova

Copyright (C) 2020. Vera SAMARINA, Tatiana SKUFINA, Elena KORCHAK, Natalia SEROVA and Aleksandr SAMARIN. Distributed under Creative Commons Attribution 4.0 International CC-BY 4.0

\begin{abstract}
The authors have presented the research of Arctic strategies for the socio-economic development of circumpolar states with the identification of national and regional aspects. The research seems to be very relevant because of the growth of geopolitical and economic importance of the Arctic. Countries with Arctic territories together and individually develop legal framework of a country, taking into account the following: firstly, their priorities; secondly, the existing legal status of land, water and air spaces of the Arctic; thirdly, global interests of the present and future of the planet. In the presented paper, the authors have revealed some key priorities of the state Arctic policies of circumpolar countries on the base of the analysis of political and programmatic documents. The analysis of political and programmatic documents has shown that the state Arctic policies of the circumpolar countries are focused on expanding external interaction in the Arctic and maintaining the sustainable development of their own Arctic territories. Certain of main disadvantages of the circumpolar countries' Arctic strategies have been determined. According to the analysis of the conceptual framework and key priorities of the Arctic policies of the circumpolar countries, the conclusion concerning declarative nature of national Arctic strategies has been drawn. It has been shown that regional strategies of the Arctic territories are the basis for the implementation of the circumpolar countries' state policies. The development of such strategies is based on national priorities and regional opportunities.
\end{abstract}

Keywords: Arctic strategies, national aspects, regional aspects, circumpolar states.

Cite this Article as: Vera SAMARINA, Tatiana SKUFINA, Elena KORCHAK, Natalia SEROVA and Aleksandr SAMARIN (2020)," Arctic Strategies for Socio-Economic Development of Circumpolar States: National and Regional Aspects", Journal of Eastern Europe Research in Business and Economics Vol. 2020 (2020), Article ID 108960, DOI: $10.5171 / 2020.108960$ 


\section{Introduction}

The relevance of the research is determined by the following: in recent decades, the so-called "polar fever" i.e. the activities of some states in the use of arctic natural resources and territories has intensified in the Arctic. The fact is that large reserves of oil, natural gas, coal, and other hydrocarbon resources have been discovered in some arctic seas and on the continental shelf of the Arctic countries. Arctic waters are rich in animal resources, including marine animals, fish, shellfish and other commercial species (Jorgensen, 1990; Larchenko et al, 2019; Sachs and Warner, 2001; Skufina et al, 2019a).

Owing to global warming and ice cap displacement to higher latitudes, some new opportunities of the Northern Sea Route are being revealed. One of them is a new transport route that can connect Russia, the USA, China, Japan, the EU countries, opening up global economic opportunities. The authors will illustrate the efficiency of this transport highway use with two examples: the distance from the port of St. Petersburg to the port of Vladivostok along the Northern Sea Route is 7559 nautical miles (NM), and the alternative route through the Suez Canal is 1.64 times greater - $12419 \mathrm{NM}$; the distance from the port of Yokohama to the port of Murmansk on the Northern Sea Route is $5770 \mathrm{NM}$, and through the Suez Canal it is 2.2 times greater $-12840 \mathrm{NM}$.

One cannot ignore the Arctic's substantial military potential. Some of circumpolar countries' borders pass along the Arctic Ocean. In the Arctic, there are enterprises of defense-industrial sector, land, air and sea military bases, airfields, and other military infrastructure of the circumpolar states (Killaby, 2006; Skufina et al, 2015).

At the same time, there is no unified international legal center that lays down legal norms and rules of activity in the Arctic. Circumpolar states in common and each individually develop legal framework of countries, taking into account, firstly, their priorities; secondly, the existing legal status of the Arctic's land, water and air spaces; thirdly, global interests of the present and future of the planet.

The purpose of the research is to reveal some conceptual foundations and key priorities of the circumpolar states' Arctic policies.

In order to achieve this goal based on the analysis of political and programmatic documents, it is necessary to solve the following problems:

- $\quad$ to reveal the key priorities of state Arctic policies of the circumpolar countries;

- to identify main drawbacks of the Arctic strategies of the circumpolar countries;

- to reveal the nature of the relationship between national and regional Arctic strategies for the socio-economic development of the circumpolar states.

\section{Materials and Methods}

Representing the methods by which the problems and purpose of the research can be solved, first of all, the authors would like to pay attention to the object of the research. The legal regime of a territory depends on the determination of its borders and components. In the scientific community and in legal literature, the Arctic is considered the northern polar region of the Earth, which includes the North Pole and is limited by the 66th northern parallel, the so-called "Arctic Circle" (Raspotnik, 2018; Jensen and Hønneland, 2015). The Arctic includes significant land areas, parts of the Arctic, Pacific and Atlantic oceans and extensive airspace.

Circumpolar states are otherwise called subarctic ones (Kefferpütz, 2010; Nordquist et al, 2010; Hassan and Karim, 2018; Steinberg et al, 2018; Skufina et al, 2019b). The research focused on the political-programmatic and legal documents of the circumpolar states. 
The research methods are directly related to the object, subject, aim and problems of the research which is based on general scientific methods. The authors will not dwell on them because of their predetermination in any research. Among interdisciplinary methods, the authors shall note a sociological one, involving the research of the Arctic policies of the circumpolar states from the standpoint of regulation of social interaction on the basis of specific facts, phenomena and processes taking place in the society between groups of people as subjects of law. In addition to this, the authors shall note a concrete historical method that will make it possible to study the Arctic policy of the circumpolar states in the process of development over time, accompanied by changes and improvement. As special methods, the authors will use a dogmatic method, which will make it possible to study the process of formation and realizing of the Arctic policy of the circumpolar states in logical order using special legal terms and constructions. It is also supposed to apply a comparative legal method, which provides systematic and comprehensive research and comparison of legal features of different countries.

The research has carried out a comparative analysis of the conceptual foundations and key priorities of the Russian Federation's Arctic policy and the policies of other circumpolar countries based on the analysis and comparison of their national Arctic strategies and other political and programmatic documents used as research materials.

\section{Results and Discussion}

The Arctic's land area is for the most part under the sovereignty of one or another circumpolar state. The water area outside the sovereignty of the circumpolar countries is regulated by general international legislation.

All eight circumpolar countries are parts of the international organization "The Arctic Council". The declarations adopted by the Arctic Council present the results of the circumpolar countries' basic agreements on the cooperation in the Arctic (Spence, 2014). In addition, each of the countries with national priorities in the Arctic realizes its own arctic policy enshrined in the political and programmatic documents.

Russia has the largest Arctic territory, the longest border, passing through the Arctic's territory and the longest sea coast in the Arctic Ocean. The priority of the Arctic for Russia will be expressed in the creation of a special object of public management of the Russian Federation's Arctic Zone (AZRF). The analysis of such main documents for management of the Russian Arctic as "The Basics of the Russian Federation's State Policy in the Arctic for the Period up to 2020 and the Future" (The Basics of the Russian..., 2008),"Russia's Arctic Zone Development and National Security Strategy for 2020"(Russia's Arctic..., 2013), State Program of the Russian Federation "Social and Economic Development of the Arctic Zone of the Russian Federation" (State Program of the Russian Federation..., 2019) and others has shown that the foundation of Russia's modern Arctic policy is the increased exploitation of natural resources for the development of the rest of the country. The Arctic is seen, first of all as a platform for the distribution of productive forces and government policy is aimed primarily at creating the optimal configuration of the main factors of industrial production.

The analysis of conceptual foundations and key policy priorities of the Arctic in the circumpolar countries has shown that their national Arctic policies are focused on the expansion of external interaction in the Arctic and sustainable development of their own Arctic territories.

In Sweden (Sweden's..., 2015) and Finland (Finland's Strategy..., 2013), the basis of the realization of the Arctic policy is so-called knowledge-based economy; in Denmark (Kingdom of Denmark Strategy..., 2011) and Iceland (Parliamentary Resolution..., 2011), it is green economy. The European Union's Arctic policy determines these countries' key priorities (EU Arctic policy, 2016) which are realized at the expense of regional EU funds. In Canada, Norway and

Vera SAMARINA, Tatiana SKUFINA, Elena KORCHAK, Natalia SEROVA and Aleksandr SAMARIN (2020), Journal of Eastern Europe Research in Business and Economics,

DOI: $10.5171 / 2020.108960$ 
Alaska (USA) Arctic policy's key priorities are the ecosystem approach to the exploitation of mineral and biological resources and stream of rental income to the social development of the Arctic territories. The object of Norway's modern Arctic strategy (Norway's Arctic Strategy, 2017) is the Arctic sector as a "sustainable region" where government, business and communities can cooperate together to achieve economic, environmental and social sustainability of the Arctic territories. The United States' key priority of its new Arctic strategy is strengthening of its presence in the Arctic space (DoD Arctic Strategy..., 2019).

The analysis of political and programmatic documents has shown that the significant disadvantage of the circumpolar countries' Arctic policies is the lack of a detailed elaboration of an economic-organizing mechanism of their realization (realization steps, responsible persons, specific activities, target indicators and indices, volumes and sources of financing). According to the analysis of the conceptual basis and key policy priorities of the Arctic circumpolar countries, the authors have drawn the conclusion concerning declarative character of the national Arctic strategies, whose key priorities act as intentions. The main institutions of the practical realization of Arctic policies are regional strategies of socio-economic development.

In Russia such regional strategies, for example, are the following: "The Strategy of Socio-Economic Development of the Nenets Autonomous Region for the Future until 2030" (The strategy..., 2010) "Murmansk Region's Socio-Economic Development Strategy until 2020 and until 2025" (Murmansk Region's..., 2013), "YamaloNenets Autonomous Region's SocioEconomic Development Strategy until 2020" (Yamalo-Nenets..., 2011), "The Strategy of Socio-Economic Development of the Chukchi Autonomous Region until 2030" (The Strategy..., 2016) and others. Regional strategies are developed taking into account regional opportunities based on national priorities.
In Norway, for example, such regional strategies, are the following: "International strategies for Finnmark" (International strategies..., 2015), which provide for the development of international cooperation of Finnmark County in the Barents region with the North-West of the Russian Federation, especially with the Arkhangelsk region; "FoU-strategy for Nordland 2013-2025” (FoU-strategi..., 2012), which provides for the increase in the activity of $\mathrm{R} \& \mathrm{D}$ in the development and cooperation of business, public sector and research institutions on the territory of Nordland County; "SNU-Strategy" (SNUStrategi..., 2018), concerning the management of industrial development in Tromsǿ County etc.

In Finland such regional strategies are the following: "Pohjois-Pohjanmaan maakuntaohjelma 2018-2021" (PohjoisPohjanmaan..., 2017), which provides for the sustainable development of remote Northern territories (Lapin..., 2012), aimed at ensuring sustainable industrial growth etc.

In Denmark, such a regional strategy is "The Programming document for the sustainable development of Greenland 2014-2020" (Programming..., 2014). The document determines general directions of cooperation between the European Commission and the Government of Greenland with the aim of sustainable development etc. In Sweden, the regional strategy is "Regional utvecklingsstrategi 2030 - Region Norrbotten" (Regional..., 2018); its priorities are: social, environmental and economic sustainability of Norbotten CountyIn the USA, the regional strategy is "The Northern Opportunity: Alaska's Economic Strategy" (Northern... Opportunity, 2016); its priorities are: business development, finance and investment, infrastructure, socio-economic development, entrepreneurship and innovation, increasing of economic potential, quality of life. 


\section{Conclusions}

The carried out research made it possible to draw the following conclusions:

1. The analysis of the political and programmatic documents has shown that the state Arctic policies in the circumpolar countries are different. The key priority of Russia's Arctic policy is the exploitation of natural resources based on the establishment of the optimal configuration of the main factors of industrial production. Public policies of other Arctic circumpolar countries are focused on expanding external interaction in the Arctic and maintenance of sustainable development of their own Arctic territories.

2. The essential drawback of the circumpolar countries' Arctic policies is the lack of a detailed elaboration of the economic-organizing mechanism of their realization. The main disadvantage of the Russian Arctic's strategy is the positioning of the Arctic territories as a resource base that ensures socio-economic development of the country, where against the background of the dominance of large corporations' interests, which include Arctic mining companies, some problems of the Arctic regions' social development are poorly taken into account.

3. According to the results of the analysis of conceptual framework and key priorities of the circumpolar countries' Arctic policies, the authors have come to the conclusion that the national Arctic strategies, whose key priorities operate as intentions, have predominantly declarative nature. The regional strategies for socio-economic development, whose elaboration is based on national priorities and regional opportunities, are the main institutions for the practical realization of Arctic policies.

\section{Acknowledgment}

The research was supported by the Russian Science Foundation, project № 19-1800025.

\section{References}

- DoD Arctic Strategy 2019. Report to Congress Department of Defense Arctic Strategy. (2019), [Online] [Retrieved December 15, 2019], https://media.defense.gov/2019/Jun/ 06/2002141657/-1/-1/1/2019-DODARCTIC-STRATEGY.PDF

- EU Arctic policy. (2016), [Online] [Retrieved December 15, 2019], https://eeas.europa.eu/arcticpolicy/eu-arctic-policy_en

- Hassan, D. and Karim, S. (2018), International Marine Environmental Law and Policy. NY: Routledge.

- Jensen, L.C. and Hønneland, G. (2015), Handbook of the Politics of the Arctic. USA, Edward Elgar Publishing.

- Jorgensen, J.G. (1990), Oil age Eskimos. Berkeley: Univ. of California Press.

- International strategies for Finnmark. (2015), [Online] [Retrieved December 15 , 2019], https://www.ffk.no/f/p10/if8740e6f9899-4104-a5404436b7e9f39d/finnmarkinternational-strateg.pdf.

- Kefferpütz, R. (2010), 'On thin ice? (Mis)interpreting Russian policy in the High North', Policy Brief, 205, 7-15.

- Killaby, G. (2006), 'Great Game in a Cold Climate: Canada's Arctic Sovereignty in Question', Canad. Military J., 1, 34-41.

- Kingdom of Denmark Strategy for the Arctic 2011-2020. (2011), [Online] [Retrieved December 15, 2019], http://library.arcticportal.org/1890/1 /DENMARK.pdf.

- Lapin teollisuusstrategia 2030. (2012), [Online] [Retrieved December 15, 2019],

http://www.lappi.fi/c/document_libra

Vera SAMARINA, Tatiana SKUFINA, Elena KORCHAK, Natalia SEROVA and Aleksandr SAMARIN (2020), Journal of Eastern Europe Research in Business and Economics,

DOI: $10.5171 / 2020.108960$ 
ry/get_file?folderId=349619\&name=D LFE-21939.pdf

- Larchenko, L.V., Gladkiy, Yu.N. and Sukhorukov, V.D. (2019), 'Resources for sustainable development of Russian Arctic territories of raw orientation', IOP Conference Series : Earth and Environmental Science, 302, 012121.

- Murmansk Region's Socio-Economic Development Strategy until 2020 and until 2025, (2013), [Online] [Retrieved December 15, 2019], https://minec.govmurman.ru/activities/strat_plan/sub0 2/

- Northern Opportunity: Alaska's Economic Strategy, (2016), [Online] [Retrieved August 10, 2019], https://www.commerce.alaska.gov/w eb/ded/DEV/AKEconomicStrategy.asp $\mathrm{x}$

- Nordquist, M., Moore, J. N. and Heidar, T. H. (2010), Changes in the Arctic Environment and the Law of the Sea. Bosnon: Lieden Pub.

- Parliamentary Resolution on Iceland's Arctic Policy, (2013), [Online] [Retrieved December 15, 2019], https://www.government.is/media/ut anrikisraduneytimedia/media/nordurlandaskrifstofa/A -Parliamentary-Resolution-on-ICEArctic-Policy-approved-byAlthingi.pdf.

- Pohjois-Pohjanmaan maakuntaohjelma 2018-2021, (2017), [Online] [Retrieved December 15, 2019], https://www.pohjois-

pohjanmaa.fi/aluesuunnittelu/maakun taohjelma_ja_-

suunnitelma/maakuntaohjelma_20182021.

- Programming document for the sustainable development of Greenland 2014-2020, (2014), [Online] [Retrieved December 15, 2019], https://ec.europa.eu/europeaid/progr amming-document-sustainabledevelopment-greenland-2014-2020_en

- Raspotnik, A. (2018), The European Union and the Geopolitics of the Arctic. Northampton: Edward Elgar Pub.

- Regional utvecklingsstrategi Region Norrbotten, (2018), [Online] [Retrieved December 15, 2019], https://www.norrbotten.se/Utvecklin g-och-tillvaxt/Regional-utvecklingoch-framtid/Regionaltutvecklingsuppdrag/Regionalutvecklingsstrategi/

- Russia's Arctic Zone Development and National Security Strategy for 2020, (2013), [Online] [Retrieved December 15 , https://legalacts.ru/doc/strategijarazvitija-arkticheskoi-zony-rossiiskoifederatsii-i/

- Sachs, J. and Warner, A. (2001), 'The curse of natural resources,' European Economic Review, 45, 128-132.

- Samarina, V.P., Skufina, TP. and Samarin, A.V. (2018), 'Russia's North Regions as Frontier Territories: Demographic Indicators and Management Features, ' European Research Studies Journal, XXI (3), 705716.

- Samarina, V., Samarin, A., Skufina, T. and Baranov, S. (2019), 'The Population Settlement in Russia's Arctic Zone: Facts and Trends', IOP Conference Series: Earth and Environmental Science, 302, 1.

- Skufina, T., Baranov, S. and Samarina, V. (2019a) 'Modeling the Production of GRP Regions of the North of Russia', Smart Technologies and Innovations in Design for Control of Technological Processes and Objects: Economy and Production. FarEastCon 2018. Smart Innovation, Systems and Technologies, $139,173-179$.

- Skufina, T., Baranov, S., Samarina, V. and Samarin, A. (2019b), 'Natural

Vera SAMARINA, Tatiana SKUFINA, Elena KORCHAK, Natalia SEROVA and Aleksandr SAMARIN (2020), Journal of Eastern Europe Research in Business and Economics,

DOI: $10.5171 / 2020.108960$ 
resources as a factor of socio-economic development of the Arctic territories: theoretical components of the research problem, ' IOP Conference Series: Earth and Environmental Science, 302, 1.

- Skufina, T.P., Samarina, V.P., Krachunov, H. and Savon, D.Yu. (2015), 'Problems of Russia's Arctic development in the context of optimization of the mineral raw materials complex use', Eurasian Mining, 2(24), 18-21.

- Spence, J. (2014), 'Strengthening the Arctic Council: Insights from the architecture behind Canadian participation,' Northern Review, 37, 112-118.

- State Program of the Russian Federation "Social and Economic Development of the Arctic Zone of the Russian Federation", (2019), [Online] [Retrieved December 15, 2019], https://legalacts.ru/doc/postanovleni e-pravitelstva-rf-ot-21042014-n-366/.

- $\quad$ Steinberg, P. E., Tasch, J., Gerhardt, H., Keul, A. and Nyman, E.A. (2018), Contesting the Arctic: Politics and Imaginaries in the Circumpolar North. Bloomsbury: Bloomsbury Pub.

- Sweden's Strategy for the Arctic Region. (2015), [Online] [Retrieved December 15, 2019], https://www.government.se/countryand-regionalstrategies/2011/10/swedensstrategy-for-the-arctic-region/.

- The Basics of the Russian Federation's State Policy in the Arctic for the Period up to 2020 and the Future. (2008), [Online] [Retrieved December 15, 2019], https://rg.ru/2009/03/30/arktikaosnovy-dok.html.

- The Strategy of Socio-Economic Development of the Chukchi Autonomous Region until 2030. (2016), [Online] [Retrieved December 15 , 2019], http://docs.cntd.ru/document/44612 3709.

- The Strategy of Socio-Economic Development of the Nenets Autonomous Region for the Future Until 2030. (2015), [Online] [Retrieved December 15, 2019], http://www.csrnw.ru/files/csr/file_content_581.pdf.

- SNU-Strategi for næringsutvikling $\mathrm{i}$ Troms 2018-2025. (2018), [Online] [Retrieved December 15, 2019], https://snu-troms.no/

- The United Nations Population Fund: World Population. (2018), [Online] [Retrieved December 15, 2019], https://gtmarket.ru/ratings/worldpopulation/info.

- The World Bank: Gross Domestic Product. (2019), [Online] [Retrieved December 15, 2019], https://gtmarket.ru/ratings/ratingcountries-gdp/rating-countries-gdpinfo.

- Finland's Strategy for the Arctic Region. (2013), [Online] [Retrieved December 15, 2019], https://vnk.fi/documents/10616/109 3242/J1613_Finland\%E2\%80\%99s+St rategy+for+the+Arctic+Region.pdf/cf8 0d586-895a-4a32-8582$435 \mathrm{f} 60400 \mathrm{fd} 2$ ?version $=1.0$.

- FoU-strategi for Nordland. (2012), [Online] [Retrieved December 15, 2019], 2013-2025 https://www.nfk.no/_f/p34/i1f10176f -1a0f-467f-97b1-6f45a8fd09c2/foustrategi-for-nordland.pdf

- Yamalo-Nenets Autonomous Region's Socio-Economic Development Strategy until 2020. (2011), [Online] [Retrieved December 15, 2019], https://www.yanao.ru/activity/2234/ 